The University of Akron

\title{
IdeaExchange@UAkron
}

Proceedings from the Document Academy

University of Akron Press Managed

January 2016

\section{A Documentologic Approach of Herbarium: Documentary Anabiosis and Philogenetic Classification}

Viviane Couzinet

Université Paul Sabatier Toulouse France, viviane.couzinet@iut-tlse3.fr

Please take a moment to share how this work helps you through this survey. Your feedback will be important as we plan further development of our repository.

Follow this and additional works at: https://ideaexchange.uakron.edu/docam

Part of the Library and Information Science Commons

\section{Recommended Citation}

Couzinet, Viviane (2015) "A Documentologic Approach of Herbarium: Documentary Anabiosis and Philogenetic Classification," Proceedings from the Document Academy: Vol. 2 : Iss. 1 , Article 16.

DOI: https://doi.org/10.35492/docam/2/1/16

Available at: https://ideaexchange.uakron.edu/docam/vol2/iss1/16

This Conference Proceeding is brought to you for free and open access by University of Akron Press Managed at IdeaExchange@UAkron, the institutional repository of The University of Akron in Akron, Ohio, USA. It has been accepted for inclusion in Proceedings from the Document Academy by an authorized administrator of

IdeaExchange@UAkron.For more information, please contact mjon@uakron.edu, uapress@uakron.edu. 


\section{Introduction}

Documentology was defined as the science of documents by Paul Otlet (1934) in his Traité de documentation: Le livre sur le livre, théorie et pratique ${ }^{1}$ and was later taken up by Jean Meyriat (1981/2001) in the article "Document, documentation, documentologie," originally published in the journal Schéma et Schématisation. In France, this last article is considered the foundational text in establishing the document as a major concept in information science; it argues that utility is a dimension of the concept, and it establishes the active role of the user in recognizing a document as such. Meyriat also hoped the concept of documentology would gain traction; however, unlike document, the term documentology remains little used in information science.

This paper presents the thread of my research since 2013, in which I have been exploring how the phylogenetic classification system used in botany can serve as a general model for classifying documents. I define documentology as the study of mediation through documents. This definition brings to light the importance of the user and their context in the construction of a document. The proposed approach is thus social and sits well within the Francophone school of document studies, in which Jean Meyriat is the major theoretician. Drawing from Meyriat's (1981/2001) conceptualization of documentology, I have developed the descriptive method of documentography. I first implemented this method in analyzing the evolution of French land registration documents cadastres) from the 17th century to todayfrom paper to electronic data. Through the examination of these documents in their historically evolving forms, the concept of documental filiation emerged. More recently, in studying botany, I have extended this into the notion of documental phylogeny, which contributes to recent interest in taking an evolutionary approach to the sciences.

But a method and a theoretical approach are valid only if they can be, at least partially, generalized. This evolutionist approach seeks to provide a way to identify the phylogenetic precursors of any document in its socioeconomic context. Two $\mathrm{PhD}$ research projects are ongoing in the information and communication sciences (ICS) at the University of Toulouse- one on maps and the other on baby books - which will further test and develop the approach and method.

For rigor, it is necessary to study documental forms that are not limited to text and images. How can other forms be gathered into a directory of documents? What not-yet-identified elements must be taken into account? To answer these questions, empirical work is being conducted on heritage objects at the herbaria of the National Museum of Natural History in Paris and the University of Toulouse.

\footnotetext{
${ }^{1}$ This title would be rendered in English as Treatise on Documentation: The Book on the Book, Theory and Practice. While this work is not available in English, a selection of Otlet's essays has been translated and published by W. Boyd Rayward (Otlet, 1990).
} 
The documents under study consist of electronic data, concrete objects (and their pictorial representations) and texts produced by botanists.

This research seeks to contribute to the development of the documentological branch of ICS by adapting tools and constructing corpora from the field of botany that could aid in the analysis of documents in general.

The first part of this paper synthesizes the foundational works in the social approach to document studies. The second part describes the initial research on the textual and pictorial documents that inspired my phylogenetic approach, followed by a description of the herbaria which comprise the most recent corpus and the application of the documentographic method. Finally, the third part will discuss the biological model of phylogenetic classification and its adaptation for documentology.

\section{Background}

In the Francophone world, the concept of document was first developed nearly a century ago by the same authors who built the foundation of ICS in general. In this section I seek to clarify the concept by taking into account the historical context of this development and the viewpoints of key French writers who worked on the concept, within which I situate my own work.

\section{Pioneering Works}

The reference for research on the document is Paul Otlet's (1934) Traité de documentation: Le livre sur le livre, théorie et pratique. As a lawyer, Otlet took as a starting point the legal definition of the word, "written proof or information" (Rey, 1995, p. 620), a meaning that extended to the 17th century. Otlet created around 1907 a "general information directory" to aggregate facts, patents and records from various institutions. Twenty years later, as his purposes evolved, he defined document as a "medium of a certain material and size, possibly folded or rolled, on which are inscribed signs that represent intellectual data"2 (Otlet, 1934, p. 43). Document was then considered synonymous with book. As Otlet was primarily interested in how books were dealt with in libraries, he also gave another dimension to his words by implicitly defining bibliology/documentology as book/documentation science. He then described its purpose, foundations, methods and relationship with the other sciences. As documentology evolved, the focus moved from books to more diverse types of documents, no longer limited to texts (Otlet, 1934, pp. 9-42).

2 "Un support d'une certaine matière et dimension, éventuellement d'un certain pliage ou enroulement sur lequel sont portés des signes représentatifs de certaines données intellectuelles." 
Suzanne Briet, a librarian in the library science movement-which is to say, a focus on the management of libraries and reflection on books - also belonged to this tradition of considering documents in a variety of media. She introduced the notion that a living thing can be a document if its existence is rare or special. Indeed its rarity and specialness compel the production of secondary documents to make it more widely known. She took an active part in renewing discussions about the professional practice of documentation and how it could take diverse and new media into account. Her book What Is Documentation? (Briet, 1951 ) is a manifesto for the practice of documentation. For her, this practice justified the creation of a profession and technical training, ${ }^{3}$ which was borne out with her help through the National Institute of Documentary Techniques (INTD), an entity not linked to the Ministry of Culture as libraries are, but rather to technical education: INTD is part of the National Conservatory of Arts and Crafts. Thus the purpose of INTD was not only to train book specialists but to train people to document facts, events and discoveries. The profession of documentation also became involved in the development of scientific techniques during the reconstruction efforts after WWII and later industrial development. Her book remains a reference for researchers studying documentation in its professional dimensions. In it, she describes documentation as a dynamic job where the priority is to inform rather than preserve. This position, shared by other librarians, earned her some trouble within the French National Library. Suzanne Briet's contribution has been highlighted by Michael Buckland (1997) in Anglophone countries.

\section{Jean Meyriat's Contribution}

In the 1960s, a movement that would lead to the creation of the Association of Documentalists and Specialized Librarians ${ }^{4}$ (ADBS) in Paris claimed the right for documentalists to be trained in universities and conduct research on documentation. In 1966, the first training sessions were opened in the University Institutes of Technology and a higher education program in documentation was formalized in 1975. Unique to what existed at the international level, it combined information science and communication science as ICS. The link between both was to be built through their status as sciences.

A research group called Writing and Documents was formed in 1979 by Jean Meyriat, Director of Documentation Services at the Institute of the Political Studies and Academic Director at the School for Advanced Studies in the Social Sciences, and Robert Estivals, Professor at the University of Bordeaux III and a

\footnotetext{
${ }^{3}$ Presented in the formal ministerial decree Arrêté du ler décembre 1950.

${ }^{4}$ Founded as Association des documentalistes et bibliothécaires spécialisés in 1963, the organization changed its name in 1993 to Association des professionnels de l'information et de la documentation but retained the acronym ADBS.
} 
specialist in book history, with both Meyriat and Estivals as group managers (Couzinet, 2000). This group re-established bibliology as the science of written works, part of documentology, which was itself included in ICS. They built the theoretical foundations of the discipline and reified a set of concepts that would lead to an international encyclopedia (Estivals, Meyriat and Richaudeau, 1993).

The definition of document on which the discipline was founded was articulated in 1981 in an article by Jean Meyriat entitled "Document, documentation, documentology" (1981/2001). This text followed other publications (e.g., Meyriat, 1978) explaining the function of documentation. Meyriat suggested that the notion of document should be understood in its informational and communicational dimensions. He set aside questions of medium and focused instead on document production. He distinguished the intentional production of a document (document by intention) from the attribution of the label document (document by attribution). He then made the link between the informational content, the role of the producer and the role of the user: A document may have been produced as such (document by intention), but it only truly becomes a document if the user recognizes it as such and "activates" the information within it. Meyriat thus distinguished dormant information from active information in terms of production (the creation of dormant information) and reception (the activation of information).

This approach, which combined information and communication, was supplemented by an extension of the notion of document, probably because Jean Meyriat was under the influence of the new history scholars he met at the School for Advanced Studies in the Social Sciences, where Meyriat trained PhD students. This extension recognized a document as any kind of material object, not necessarily designed to be a document, but understood as such by the user (document by attribution).

\section{Recent Works}

More recently, within the research paradigm of computer science, a group known as Pédauque (2006) launched a collective reflection on the digital document. This group, composed of professionals and researchers in both computer science and information science, focused on the technical and economical aspects of the textual or pictorial document in the digital context. This group focused on form, content and digital delivery, and their works have been widely spread.

Other research by specialists in information retrieval highlighted, like Meyriat, the role of the user. Considering works from philosophers of history, they showed that the user's questioning guides the information retrieval process and that the act of questioning transforms an object into a document (Metzger, 2008). For these scholars, this transformation involves three domains: the document domain, 
the social domain and the represented or discourse domain. Each of these three domains includes a temporal dimension from which even digital documents are not unbound (Metzger and Lallich-Boidin, 2004).

My research in documentology started in 1984 and continued throughout the years in a very episodic way, resulting in several publications and the direction of a number of doctoral theses. I work within a research group that analyzes specialpurpose media; we focus on the social dimension of documents. We are researchers from various scientific backgrounds (history, literature, art, archeology...) gathered in ICS. Following the work of Jean Meyriat, we are interested in the construction and social reception of any object that may become a document. We conduct empirical research in order to clarify the definition of document, as well as to try to explain documental mediation. We seek to understand what can become a document if questioned by a user. We analyze how intention and attribution are expressed in form and style in specific domains. We seek to understand in particular the process of documental hybridization-when a document sits between disciplines or is used by diverse recipients (Couzinet,2009a). We also combine this research on documental mediation with research on cultural mediation, which looks at the role of documents in defining heritage objects.

\section{Towards a Renewal of Documentology}

\section{First Definitions}

The word documentology refers in general to the theoretical foundations, motivating questions and practical processes in the field of documentation, which arise through reflection on empirical data and written texts. For Paul Otlet, the development of printing, education, libraries and the media, as well as science and technology, have made such reflection necessary.

Jean Meyriat, thirty five years later, returned to the term to clarify it. Documentology, as he specified, is a scientific view of the document because, for him, "there is room indeed for a general science of the document, regardless of the language that it uses: written, auditory, pictorial, digital" (Meyriat, 1993, p. 152) It brings together sciences that "have a common focus on media created to preserve and communicate; these are aspects of what documentology has studied"6 (p. 152). He placed documentology within communication science.

Therefore documentology focuses on the informational value of objects. In

\footnotetext{
5 "Il y a place en effet pour une science générale du document, quel que soit le langage auquel il recourt : écrit, sonore, iconique, numérique"

6 "qui ont en commun d'être des supports d'information, créés en vue de la conserver et de la communiquer : ce sont tous les aspects liés à cette fonction commune qu'étudie la documentologie"
} 
other words, it concerns the role of objects as mediators. It is interested in everything that is involved in the production and consumption of this information in all its possible representations. This echoes the notions of intention and attribution in the mediation of knowledge production, which can be studied separately or complementarily. We can say that, from a social perspective, the concept of document consists of four dimensions: context, informational value, medium and content (Couzinet, 2004).

From these defining elements, I undertook a study of a particular type of document, which is little studied nowadays: those used to establish land ownership and property taxes in France. My objective was to verify whether the documentological perspective, as the science of documents, could illuminate specific items that should be observed in this study. In extending previous work, I also hoped to further define the scientific method of documentology.

\section{History's Contribution: The Temporal Dimension of the Document}

An earlier thread of my research examined the document from a historical perspective (Couzinet, 2004), and attending a historical research seminar in 2014 invited me to improve upon my historical method. To do that, I analyzed land registration records from the south of France, comparing those in their 17th-century paper form (called compoix) and their digital representations to the born-digital records of today (Couzinet, 2014).

The first step of this research was to create an accurate description of the characteristics of the records, which I did using the original version and digital representations available on the Internet. In the 17th century, these records often contained text and maps. Over time, however, the text and the maps were sometimes separated. Today the maps are readily accessible, but the textual data is only accessible under certain conditions, as it contains information about private individuals.

I also studied the secondary documents that allowed me to locate the records and retrieve the information. The purpose of this was to understand what archivists and tax professionals saw as essential in describing the records. To compare the informational within the 17 th-century records to the modern-day records, I analyzed the development of how the documents were used in different situations over time.

This research highlighted how a specific method could be used to create a list of the documents by intention in their context; the document by intention is the major object of study in documentology. I call this method the documentological method. It combines the description of documents, called documentography, with a contextualized content analysis, which I call documentological analysis. The documentological analysis focuses on the document's construction, informational 
value, content and identity (Couzinet, 2004). Research on documental filiation was based on describing the modern-day documents, which were secondary or even tertiary documents - including drafts and library collection insertions, both digital and not. This collection of derived documents is itself a recognizable documental resource that relates to the information contained within the documents under study. The content analysis was based on the manual or computerized tracking of meaningful terms across document derivations that could then be aggregated, compared, separated and prioritized (Couzinet, 2015).

The purpose of this research was therefore to analyze what information is retained and what is changed over time in order to understand the weight a particular document has in today's society. As developed by Meyriat, documentology allows a document to be analyzed as an evolving entity. Such genealogical work puts into perspective the "novelty" of documents circulating on the Internet (Couzinet, 2014).

Finally, my research on this subject helped clarify and prioritize key concepts, thus also serving to clarify the boundaries of our discipline in the same way that Jean Meyriat (1983) and Robert Estivals (1993) previously did. Estivals' bibliological method of classification was shown to be applicable in ICS (Couzinet, $2008 ; 2009$ b), but it seemed to me that this method, along with a documentological approach in general, could be used for epistemological analysis in other disciplines.

\section{Herbarium as Document}

The methods established for analyzing written and pictorial documents remained to be validated for analyzing concrete objects. A chance visit to the National Museum of Brazil, which operates under the auspices of the Federal University of Rio de Janeiro, sparked the idea of taking a model from plant biology, a science to which information science has little recourse. Plant biology has devised an inventory of all plants, taking into account their evolution.

The activity of science is largely characterized by the classification and preservation objects of knowledge. Science presents a vast collection of specimens which promote an understanding of the variety, environmental adaptation and evolution of humans, plants and other organisms, accounting also for how they are related to each other. These specimens are, therefore, documents.

Plants are particularly important objects of study because they are used for the feeding, hygiene and health of humans and animals, and consequently they are vital to many agricultural and industrial activities. Herbaria present collections of preserved and dried plants, thus allowing researchers to perceive evolutionary developments and better understand, for instance, climate change. With such important ends in mind, an inventory of the world's biodiversity became 
necessary. $^{7}$

The plant heritage of my university consists of live specimens grown in the Botanical Gardens of Toulouse and the Arboretum Henri Gaussen near the Pyrenees mountains, as well as 400,000 inert preserved plant specimens. It also includes the College of Pharmacy's droguier, which is a room where pharmaceutical plants are collected and preserved in jars for later medicinal use. The plant heritage is managed by the Common Service for the Study and Preservation of Heritage Collections.

The Herbarium of the University of Toulouse has about $300,000^{8}$ plant sheets distributed in sixty different physical herbaria. The collection consists of mushrooms, lichens, mosses, flowering plants, algae and conifers collected by researchers and students during their research in the south of France and abroad since 1811. In order to unify the methods of documentation among these physicallydistributed herbaria, a centralized database of these specimens, called Flora, is being produced in partnership with the Botanical Conservatory of the Pyrenees. A plant sheet digitization project is currently underway with the University of Montpellier. In this research, it was necessary to compare physical and digital herbaria; because the digital herbarium of the University of Toulouse is not yet available, observations were conducted on other digital herbaria. Herbaria accessible through the National Museum of Natural History (MNHN) website ${ }^{9}$ were examined.

\section{Phylogenetic Classification and Documental Anabiosis}

\section{Documentation in the Herbarium}

The first herbarium in the current sense of the word (i.e., a collection of plants or dried mushrooms), also the oldest MNHN herbarium, was established in Pisa in 1530 by a medical student. Until the 17th century, however, the word herbarium referred to books of botanical illustrations. As the illustrations were drawn from specimens taken from the field for the purpose of future identification, they can be considered a form of laboratory notebook. Such books were kept in botanical gardens where medicinal plants were grown, and they aided in the establishment of droguiers at medical colleges. These methods of plant preservation, then, were aimed at improving knowledge of plants ultimately to care better for humans.

\footnotetext{
${ }^{7}$ The Biodiversity Heritage Library offers free access to the world's biodiversity knowledge at http://biodiversitylibrary.org

${ }^{8}$ The number of plant sheets is not necessarily equal to the number of preserved specimens. A single plant sheet can contain a number of distinct specimens (e.g., blossom, fruit, leaf, seed) which represent different stages of the development of the species.

${ }^{9}$ http://coldb.mnhn.fr/
} 
A common plant collection technique is to place the specimens between sheets of newspaper to dry. Typically specimens would be moved after drying, but some MNHN herbaria were kept in this state. Thus the project of digitization has also been an opportunity to improve the storage conditions of the physical collections. Properly preserved, the plant is secured on board by glue, thread or an overlay, and then annotated. These annotations are made either directly on the board alongside the plant or on labels which are then fixed to the board. The electronic database also refers to related documents, such as registries, collection notebooks or DNA samples. On the digitized specimen, a code appears on the image which is used to identify the physical plant.

So we can say that an herbarium is the result of three stages of work. The first stage involves the collection of the plant. A plant is generally chosen for collection because of its peculiarity and its usage by the people who share its environment. The second stage is the production of annotations within a predetermined framework, recording the physical characteristics of the plant as it appears in the field, sometimes with drawings of its appearance in different states. These annotations are first recorded in diaries or notebooks and then transferred to the herbarium sheet in the form of a label. Finally, the third task is to name and identify the plant, which first involves the comparison with other plants to determine the category to which it belongs.

The process of documentation in the herbarium is intended to share knowledge. Originally for improving medical care, this documentation now aids in preserving biodiversity, responding to humanitarian and economic interests. It is based on the production of secondary documents - labels - and, at each stage, the classification of specimens, either within the framework already established or according to a newly proposed organizational scheme. Herbaria are documents by intention, at once textual, pictorial and physical.

\section{The Botanist's Work}

The botanist's core activity is documentation. Indeed, botany is a science of observation and description, whose objective is to understand the organization and evolution of the plant world. For this reason botanists collect, describe, name and classify plants. They most often collect plants during expeditions, such as that of Nicolas Baudin in the South Seas and Australia (then "New Holland") in 1801. Upon their return, explorers and scholars deposit their collection so that they can be studied. Nowadays, public or private research laboratories are the primary botanic collectors, but the process has remained fundamentally the same.

After the Renaissance, botanists classified plants according to their visible characteristics, and many classification schemes were used. Linnaeus, for example, classified plants by the shapes of the stamens and pistils; Jussieu, a father and son, 
did so based on shared characteristics. Nowadays botanists favor classification schemes that take into account the evolution of the plant and establish its relationship with other plant species. By analyzing all the information available on any plant, botanists build trees called phylogenies. These trees are not complete, however, because the earliest ancestors are not known. Moreover, the trees are constantly changing as new information and analytical methods, such as DNA indexing, leads to reorganization.

From my conceptualization of the herbarium as a document by intention, it becomes possible to develop an inventory of the mediating objects involved-not only the textual and pictorial ones, but also the concrete objects. This suggestion should be confirmed through further studies-on geological specimens, for example. To this end, a study on holy relics is currently underway in my research group (Fraysse, 2014).

This work also establishes the possibility to develop, from within information science, a documentological approach to other sciences. It would explore how to collect, classify and name specimens, and how documentation and the production of information causes a science to progress. Indeed, this aspect of a scientist's work is often invisible, but it is important; my analysis of the herbarium and the consequent view of botany as documentation proved richer than expected.

\section{Botany's Contribution to Documentology}

To classify plants, botanists use phylogenies, which take into account the evolution of the plant. The study of relatives begins with the analysis of visible characteristics and is completed by the analysis of chemical and genetic components.

Documentology, as I see it, attempts to dig into the roots of documents. In other words, documentology is the search for an understanding of our present world by looking to the past. Thus the notion of documental filiation, which I explored in my historical analysis of property tax documents, seems essential for understanding the social issues surrounding any document, including the intentions with which the documents were created. A physical herbarium is not only a storehouse of national scientific heritage, but it is also beacon of hope in fighting against diseases or a sign of the conquest of a very lucrative market. Clearly the meaning of a document changes over time. The study of a document should take into account this temporal dimension. Moreover, just as the meaning of a document changes, so does the medium. Herbaria were once only physical, but now they are digital as well. This evolution reflects the objective of the herbarium - to share knowledge in an ongoing way - and it has the side effect of opening this knowledge to the general public via the Internet rather than just to specialists. Also resulting from the desires to, on one hand, preserve artifacts, and on the other, share their knowledge, is the emerging possibility that soon only specialists will have access to physical objects. 
Documentology seems well suited for the classification of objects based on filiation and evolution. Understanding ancestry - seeing variations in their historical context - seems to me a way to better understand the present. So, based on the model of botany, I postulate that documentology can be viewed as the phylogenetic classification of documents.

Botany is also interested in the life of the plant in its natural environment. It studies the phenomena that occur as a plant passes from seed germination to its own fruiting, including its nutritional and fluid requirements, etc. Of all these phenomena, one particularly calls my attention: its dormancy. Dormancy is the period when a plant pauses its development. We can recall the documents by intention described by Meyriat (2001), which are created to inform but which only do so when their information is invoked through a user's questioning. So there is a documental dormancy, analogous to that of the plant. This analogy can be completed by anabiosis, another concept from botany. Anabiosis is the coming back to life of an organism after it has been in a suspended state of latent life, usually imposed by the temporary absence of water. Transposed to documentology, I posit a documental anabiosis, which I would define as the transformation of a physical object into a document while it was not originally intended for this purpose. Documental anabiosis would be the change of state from being a mere physical object to being a document, triggered by the questioning of a person who wants to use the object for information. Every object, then, is a latent document by lack of interest; the attribution of interest triggers anabiosis and turns it into a document.

\section{Conclusion}

After this discussion, we can say that physical objects can be included in an inventory of documents if the intention that led to their construction is taken into account. Considering the temporal, historical dimension seems to help us better understand them in their present contexts, but further research should be done in this regard.

Finally, observations on the work of botanists and the science of botany have furthered the conceptualization and methods of documentology. Moreover, it seems possible to articulate a documentological approach to science in general. 


\section{References}

Briet, S. (1951). Qu'est ce que la documentation? Paris: Editions Documentaires et Techniques. $^{10}$

Buckland, M. (1997). What is a document? Journal of the American Society for Information Science, 48(9), 804-809.

Couzinet, V. (2000). Médiations hybrides: Le documentaliste et le chercheur en sciences de l'information. Paris : ADBS Éditions.

Couzinet, V. (2004). Le document: Leçon d'histoire, leçon de méthode. Communication et Langages, 140, 19-29.

Couzinet, V. (2008). Représenter, répertorier, transmettre: formes d'institutionnalisation d'une discipline. In R. M. Marteleto, I. Thiesen (Eds), Mediações e Usos de Saberes e da Informação: um diàlogo França-Brasil, (pp. 63-138). Universidade da Rio de Janeiro (Brazil) \& MUSSI Ed.

Couzinet, V. (2009a). Complexity and document: The hybridization of mediations in areas undergoing rupture. RECIIS, Electronic Journal of Communication Information and Innovation in Health, 3(3), 10-16. doi:10.3395/reciis.v3i3.750

Couzinet, V. (2009b). Transmitir, difundir : formas de institucionalizaçao de uma disciplina. Perspectivas em ciencia da informaçao, 14, 5-18.

Couzinet V. (2014). Document et documentologie dans les sciences de l'information et de la communication. In K. de Carvalho \& M.I. Barreira (Eds.), As transformações do documento no espaço-tempo do conhecimento (pp. 115-138). Salvador, Brazil: Universidade da Bahia, Instituto de Ciência da Informaçao \& MUSSI Ed.

Couzinet, V. (2015). Les documents cadastraux: regard de la science de l'information-communication sur l'archive. In P. Fraysse (Ed.), SIC et histoire (25-37). Toulouse, France: Cépaduès.

Estivals, R., Meyriat, J., and Richaudeau, F. (1993). Les sciences de l'écrit: Encyclopédie internationale de bibliologie. Paris: Retz.

Estivals, R. (1993). Classification de la bibliologie. In R. Estivals, J. Meyriat and F. Richaudeau (Eds.), Les sciences de l'écrit: Encyclopédie internationale de bibliologie (pp. 112-119). Paris: Retz.

Fraysse, P. (2014). Le culte du document: La collection de reliques de la basilique Saint-Sernin de Toulouse (France). In K. de Carvalho and M. I. Barreira (Eds.), As transformações do documento no espaço-tempo do conhecimento [CD-ROM]. Salvador, Brazil: Universidade da Bahia,

\footnotetext{
10 This work is available in English in the volume What Is Documentation? (R. E. Day, L.
} Martinet and H. G. B. Anghelescu, Trans. and Eds.), 9-45. Lanham, MD: Scarecrow Press. 
Instituto de Ciência da Informaçao, \& MUSSI Ed.

Metzger, J.-P. (2010). Time, memory and document. In Papy F. (ed.), Information science (pp. 65-89). London, UK: ISTE.

Metzger, J.-P., and Lallich-Boidin, G. (2004). Temps et documents numériques. Document Numérique, 8(4), 11-21. doi: 10.3166/dn.8.4.11-21

Meyriat J. (1978). De l'écrit à l'information: la notion de document et la méthodologie de l'analyse de document. In Inforcom78 (pp. 23-32), Paris: SFSIC.

Meyriat, J. (1983). Pour une classification des sciences de l'information et de la communication. Schéma et Schématisation, 19, 61-64.

Meyriat, J. (1993). Documentologie. In R. Estivals, J. Meyriat and F. Richaudeau (Eds.), Les sciences de l'écrit: Encyclopédie internationale de bibliologie (pp. 151-152). Paris: Retz.

Meyriat, J. (2001). Document, documentation, documentologie. In V. Couzinet (Ed.), Jean Meyriat, théoricien et praticien de l'information-documentation (pp. 143-160). Paris: ADBS Éditions. (Original work published 1981)

Otlet, P. (1934). Traité de documentation: Le livre sur le livre. Brussels: Editions du Mundaneum.

Otlet, P. (1990). International organisation and dissemination of knowledge. Selected essays of Paul Otlet. (W. B. Rayward, Trans. and Ed.). Amsterdam: Elsevier.

Pédauque R. T. (2006). Document et modernités. Retrieved from http://archivesic.ccsd.cnrs.fr/sic_00001741

Rey, A. (1995). Dictionnaire historique de la langue française. Paris: Robert. 